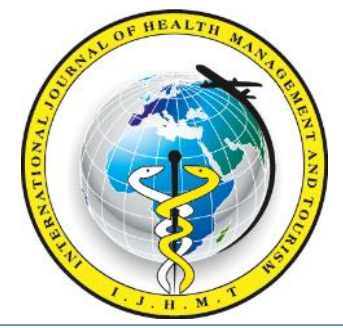

Internatıonal Journal Of Health Management And Tourism

\title{
THE EVALUATION OF THE DIGITAL MARKETING ACTIVITIES OF THERMAL FACILITIES AND JCI ACCREDITED HOSPITALS IN TERMS OF HEALTH TOURISM
}

\section{Dilaver TENGILIMOĞLU, Alper GÜZEL, Cansu AYKAN, Emre TENGILIMOĞLU, Elif BODUROĞLU}

${ }^{1}$ Professor, Atılım University, Institute for Social Scienses, Department of Healthcare Management, ${ }^{2}$ Lecturer, Gazi University, Vocational High School of Health Services, ${ }^{3}$ Post Graduate Student, Ankara University, Department of Healthcare Management

${ }^{4}$ Türk Telekom A.Ş.

${ }^{5}$ Research Assistant, Atılım University, Business Faculty

*E-mail: guzel@gazi.edu.tr

\begin{abstract}
Enterprises that operate in the field of health tourism have always had a hard time promoting the products and services to the people located in different part of the world and interacting with the target markets. Developments in information and communication technologies, internet, and mobile technologies have smoothed the ways of accessing information, shopping, socializing, having fun, and seeking for information without any time or place constraints with very low costs. Enterprises that want to benefit from the digitalized world have started to move their marketing activities to digital platforms. In this context, the goal of this study is to evaluate the digital marketing activities of thermal facilities and JCI accredited hospitals, and to compare them. This is a descriptive study, using the content analysis method to evaluate the digital marketing activities of thermal facilities and JCI accredited hospitals. The study evaluates the digital marketing activities of 73 thermal facilities, and $30 \mathrm{JCI}$ accredited hospitals. The researcher coded the collected data, and calculated frequency and percentage distributions. Frequency and percentage distributions were calculated. The results show that $38,4 \%$ of the thermal facilities do not have a web page in English or in another language. Furthermore, in contrast to accredited hospitals, there is no enough information about the staff in thermal facilities Enterprises that operate in the field of health tourism use web and social media more efficiently. Efficient use of such channels allows the health tourism enterprises interact with their target market and produce content in accordance with the needs and desires of the target market. In addition, sharing information and creating content can be considered as a strategy to attract target markets.
\end{abstract}

Keywords: Health tourism, thermal facilities, JCI, digital marketing 


\section{Introduction}

Although health tourism is a rather new concept, it has demonstrated a rapid development in recent years with the development and cheapening of means of communication and transportation in the globalizing world. Health tourism refers to travels to different countries by individuals who seek more quality healthcare services, and lower insurance costs. Lunt, Horsfall, \& Hanefeld (2016), states that these treatments mainly involve aesthetic and cosmetic, tooth surgery, cardiovascular surgery, orthopedic surgery, obesity treatment, organ and tissue transplantation, and in vitro fertilization treatment (p. 37). Service providers, mediators, and agencies who provide service under the scope of health tourism are present in the sector in order to find the hospitals and clinics at the most suitable location that could respond to their needs, and facilitate the travels of the patients by providing such services as translation, transfer, and consultancy (Lunt et. al. 2016, p. 40). According to (Hopkins, Labonte', \& Runnels, 2010, p. 187 ), service providers, mediators, and agencies who provide service under the scope of health tourism, play an important role in the development of the sector by establishing connection with the health institutions. By means of interactive, they meet requirements such as planning the health services of the individuals who are in need of health service, contacting the physicians, making the bookings for travel and accommodation, and organizing the touristic trips. (Heung, Kucukusta, \& Song, 2011, p. 997) state that advertisement and distribution canals such as internet, social media, friends and family recommendations are effective in patient preferences, and prices, the accreditation status of the hospital, fame of the hospital and the physicians are effective in the hospital preferences.

\section{Health Tourism and Digital Marketing}

Promoting the services provided for the development of health tourism in the international markets is highly important. Successful implementation of health tourism relies on informing potential patient on processes, procedures, alternatives, treatment services, tourism opportunities, travel organization, and the target countries (Crooks, Turner, Snyder, Johnston, \& Kingsbury, 2011, p. 727). Traditional marketing tools such as brochures, flyers, fairs, as well as digital marketing tools such as websites, social media platforms, and mobile applications help promote health tourism.

In its simplest terms, digital marketing is the action of carrying out the marketing activities in digital media. (Kannan \& Li, 2016, p. 23) defines digital marketing as "acquiring customers, using digital technologies, creating customer preferences, introducing the brand, and continuing the relations with the customer and thus increasing the sales", (Holder, 2008, p. 374) defines it as "using the digital canals that constitute the digital technologies towards the market in order to contribute in the marketing activities that aim at profitability and keeping the customer with a planned approach towards developing customer knowledge". According to (Yasmin, Tasneem, \& Fatema, 2015, p. 71), digital marketing reaches customers through channels that permit bidirectional interaction such as online ads, preparing e-mail, marketing the search engine, social media sites, website, mobile application, as opposed to the traditional marketing that enables a unilateral communication with the customer using channels such as digital marketing, printing, broadcasting, mail and telephone (Güzel, 2017, p. 298). 
Websites are highly important for health institutions that are directed towards international target markets in terms of reaching the potential customers in the target market. For a health institution, a website is the center of its own digital world and is perhaps the most important part of the whole digital marketing strategy. A website is the whole of documents that transfer information by means of customized texts, images, animations, videos and applications and provides various services such as e-trade, socialization, maps, news, blogs, banking, including all of the interconnected pages. By purchasing a domain name and providing hosting service, any individual, enterprise, organization, or institution is online, and the content is published. These contents could be related to any subject. A website is like a store that operates 24/7. It can have visitors every time of the day and perform various transactions. You can attract the visitor traffic to your website through various digital channels such as online ads, search engine marketing (SEM), e-mail preparation, and pay per click (PPC). This is important, but has no value on its own. The purpose is not to get the customer pay for the visit once and then leave, but to establish a continuing relationship where repeated visits of the website take place, and visitors are involved in page activities. The valuable thing here is to increase the website traffic and sustain it. (Güzel, 2017, p. 316). The website content is crucial in terms of turning a visitor into a customer, and keeping the customer. Perdue (2001) website content and marketing characteristics help messages to be more effective, increase the quality of products and services, and improve the brand image (Cormany \& Baloglu, 2011, p. 710). Knowing the target market and the characteristics of the target mass, as well as talking the common language with them is important in terms of creating the content and obtaining the desired objectives. Certain issues need to be addressed, such as the created content should communicate a professional image, should include updated information, publish photographs, use headings that attract attention, provide easy directions, ensure data reliability and simplicity of processes. In addition to this, performing various processes online - such as having an online meeting with the physician, making online booking, and learning the results online - provide convenience for the customers.

Social media, which has become more popular since the beginning of the 2000s and is named as Web 2.0, has become another important digital marketing channel for health institutions. According to Digital in 2017: Global Overview report, the number of active social media users in the world has increased by $21 \%$ in the last year and reached 2.78 billion this year, which is equal to $37 \%$ of the world's population. The number of active users who assess social media through mobile devices was determined as 2.54 billion people in January 2017 (Kemp, 2017). Facebook, which is the most popular social media platform, has 2.16 billion active users as of January 2018. Facebook is followed by YouTube with 1.5 billion active users, which is followed by Instagram with 800 million active users (Statista.com, 2018). Social media is the easiest and the most cost-friendly tool for information sharing on brands, enterprises, new products and services, as well as events (Khan \& Khan, 2012). Social media is a tool, used through computers and mobile devices that brings people together, creates, and shares content by different users, and establishes interaction. Social media technologies, in general, comprise social network sites, microblog sites, wikies, forums, and blogs, and provide a reliable environment to reach people at suitable times and for information sharing (Güzel, 2014; Osatuyi, 2013). 
Digital platforms are important communication channels for the enterprises and they are the mirrors of the organizations. These platforms allow customers to contact the enterprise and receive the information. At the end of this interaction, the experience between the enterprise and the customer can affect the image in customers' mind positively or negatively. In terms of health tourism, these platforms are very low-cost platforms without any time and location restrictions, and allows many channels for reaching potential customers located in different regions of the world. Also, digital platforms are one of the easiest way of interacting with the customers who search and require information. The starting point of this research was to examine the activities of hospitals accredited by the Joint Commission International (JCI) and thermal facilities operating in the field of health tourism, on digital platforms.

\section{Methodology}

This is a descriptive study with the purpose of examining the digital marketing activities of hospitals that have JCI accreditation and Turkish thermal facilities that operate in the field of health tourism, as well as comparing such digital marketing activities of hospitals and thermal facilities. For this purpose, researchers examined the websites of thermal facilities, social media accounts, and mobile applications of hospitals with JCI accreditation, using the content analysis method. In order to determine the number of categories included in the content analysis method, researchers used expert and academic opinions. Some categories were based on Mucan \& Özeltürkay's (2014) study. Researchers used 13 categories in examining the websites of thermal facilities, and 34 categories in assessing the website, social media platforms, and mobile applications related to hospitals.

Thermal health tourism includes health services which are generally rehabilitating and are presented together with such applications as physical treatment, rehabilitation, exercise, psychotherapy, diet under the supervision, inspection and program of the physician, in order to provide positive contributions in human health together with the environmental and climate factors in the region of thermal waters (Saturk). Thermal facilities could be defined as facilities that are established in regions where underground waters are present, which involve thermal treatment pools, baths, peloidotherapy units, and depending on the type, inhalation or drinking cure (Resmi Gazete, 2018). As of the year 2010, there are 15 facilities which have received tourism investment document for thermal purposes from the Ministry of Culture and Tourism, 50 facilities which have received tourism operation documents, and 35 facilities which have been documented by the local administration. For that reason, the facility has a total bed capacity of 29.727 (KTB, tarih yok). Under the scope of the research, websites of 75 thermal facilities that are still in operation, have been examined. Since there was no access to the website of two thermal facilities, they were left out of evaluation and the examination of digital marketing activities of thermal facilities was done on 73 facilities.

JCI, which was established by The Joint Commission in 1994, has been continuing its activities in more than 90 countries. JCI accreditation is accepted as the leader in international health services accreditation and is the global golden standard of health services. Its mission is to develop quality and safety in health services in the international society by ensuring training, publications, consultancy, and evaluation services. 1.033 health institutions have been 
accredited by JCI in the world. In Turkey, a total of 46 health institutions were accredited. 33 health institutions are accredited under the scope of health program, 4 under the scope of clinical laboratory program, 5 under the scope of daily/ outpatient care and 4 under the scope of academic medical center hospital program (JCI, 2018). Only 33 health institutions that were accredited under the scope of the hospital program were taken to evaluation to not affect the distribution. Two of these health institutions were withdrawn from the accreditation voluntarily, and one of them did not renew the accreditation after the expiration of its period, thus they were removed from evaluation. Under this scope, the sample of this research comprises 73 thermal facilities and 30 hospitals with JCI accreditation. Under the scope of research, researchers collected data between 20 - 27.03.2018 using 13 categories for thermal facilities and 34 categories for the hospitals. The numerical and percentage distributions of the data collected were calculated using SPSS 22.0 statistical package program.

\section{Findings}

Under the scope of this research, websites of 73 thermal facilities and websites, social media sites and mobile applications of 30 hospitals were taken under the scope of evaluation. Findings obtained through content analysis will be evaluated in two different groups as thermal facilities and hospitals. In this scope, you can see the findings related to digital marketing activities of thermal facilities in Table 1.

Table 1 - Categories related to websites of Thermal Plants

\begin{tabular}{|c|c|c|c|c|c|c|}
\hline & \multicolumn{2}{|c|}{ Yes } & \multicolumn{2}{|c|}{ None } & \multicolumn{2}{|c|}{ Total } \\
\hline & Number & $\%$ & Number & $\%$ & Number & $\%$ \\
\hline $\begin{array}{l}\text { Is there a website in English and in other } \\
\text { languages? }\end{array}$ & 45 & 61,6 & 28 & 38,4 & 73 & 100 \\
\hline Is there an accreditation and quality certificate? & 9 & 12,3 & 64 & 87,7 & 73 & 100 \\
\hline Information about the water quality & 41 & 56,2 & 32 & 43,8 & 73 & 100 \\
\hline Prices & 18 & 24,7 & 55 & 75,3 & 73 & 100 \\
\hline Transportation and traveling opportunities & 66 & 90,4 & 7 & 9,6 & 73 & 100 \\
\hline Information about the expert staff & 4 & 5,5 & 69 & 94,5 & 73 & 100 \\
\hline Patient safety & 8 & 11,0 & 65 & 89,0 & 73 & 100 \\
\hline $\begin{array}{l}\text { Is there any information/ guide related to } \\
\text { problems and procedures they may encounter? }\end{array}$ & 6 & 8,2 & 67 & 91,8 & 73 & 100 \\
\hline Mission statement & 16 & 21,9 & 57 & 78,1 & 73 & 100 \\
\hline Images about the facility & 71 & 97,3 & 2 & 2,7 & 73 & 100 \\
\hline Patient stories & 9 & 12,3 & 64 & 87,7 & 73 & 100 \\
\hline Does it have Facebook page? & 41 & 56,2 & 32 & 43,8 & 73 & 100 \\
\hline Does it have twitter page? & 36 & 49,3 & 37 & 50,7 & 73 & 100 \\
\hline
\end{tabular}


Of the thermal facilities that are taken under the scope of research, only $12.3 \%$ (n: 9) have accreditation and quality certificates and $61.6 \%$ (n: 45) of these facilities do not have a website in English or any other language. Accreditation and quality certificates are determining factors in the decision-making process of health tourists. Absence of this document may cause the preference to be directed towards another facility. Besides, for a health tourist who is in search of information, it is important to get this information from a page in a language that he/she can speak. The fact that the facilities do not have a page in English or any other language, may result in the tourist preferring another facility. In thermal facilities, tourists pay special attention to water quality and prices. $56.2 \%$ (n: 41 ) of thermal facilities share the information related to water quality in their facilities on their websites. Information related to prices is given on the website of $24.7 \%$ (n: 18) of the thermal facilities. Meanwhile, information related to transportation and travelling opportunities is shared on the web page by $90.4 \%$ of thermal facilities (n: 66).

Thermal facilities do not prefer to share the information about the expert staff that they employ on their websites. It was seen that the rate of thermal facilities which share this information on their websites was $5.5 \%$ (n: 4). One of the factors that affect the preference in health tourism is the competencies of the expert staff. Not sharing this information could lead to directing the preference of health tourist to another facility. Besides, the mission explains the reason of existence of a health facility, and the corporate mission statement is included on the website of $21.9 \%$ (n: 16) of the thermal facilities. Images related to the thermal facility is shared by $97.3 \%$ of the websites (n: 71). The images shared are important in terms of provided information on the facility and the section of the facility and its vicinity.

Patient safety includes the activities that are carried out in order to avoid risks that arise from reasons occurring as a result of service providers or environment where the service is provided to those who receive health services, and to prevent the patients from incurring damage. Only $11 \%$ (n: 8) of the thermal facilities share information in relation to patient safety on their websites. Besides, $8.2 \%$ of the thermal facility websites share information about the problems that patients could encounter as well as the procedures. Similarly, the patient stories occupy little place on the websites of thermal facilities. It was seen that the rate of thermal facilities which do not include patient stories and comments on their websites was $87.7 \%$ (n: 64). Campbell (2012) asserts that mouth to mouth communication and experiences of other people will increase short and long-term profitability, and sustainable better growth rates will occur (Yeoh, Othman, \& Ahmad, 2013, s. 198).

According to Digital in 2017: Global Overview report, monthly number of active social media users on the world is 2.78 billion people and this figure equals to around $37 \%$ of the global population. When the status of thermal facilities on social media is examined, it can be seen that $52.2 \%$ of the facilities (n: 41 ) have Facebook page and $49.3 \%$ of them have Twitter page. Efficient use of social media is important for establishing interaction with the customers and to retain them.

Table 2 - Categories related to websites of hospitals with JCI accreditation:

\begin{tabular}{llll}
\hline & Yes & None
\end{tabular}




\begin{tabular}{lcccccc} 
& Number & $\%$ & Number & $\%$ & Number & $\%$ \\
\hline Are there patient comments/ stories on the & 11 & 36,7 & 19 & 63,3 & 30 & 100 \\
websites? & & & & & & \\
Is online appointment possible on the website? & 29 & 96,7 & 1 & 3,3 & 30 & 100 \\
Is there information about the expert staff? & 29 & 96,7 & 1 & 3,3 & 30 & 100 \\
Is there a mission statement? & 29 & 96,7 & 1 & 3,3 & 30 & 100 \\
$\begin{array}{l}\text { Are there transportation and travel opportunities? } \\
\text { Is there any information/ guide related to }\end{array}$ & 29 & 96,7 & 1 & 3,3 & 30 & 100 \\
problems and procedures they may encounter? & 29 & 96,7 & 1 & 3,3 & 30 & 100 \\
\hline
\end{tabular}

Of the hospitals included under the scope of the research, $86.7 \%$ (n: 26) are general hospitals, $3.3 \%$ (n: 1) are branch hospitals and 10\% (n: 10) are training hospitals. $96.7 \%$ (n: 29) have international web page in different languages, English being the leading language. Of the hospitals that have JCI Accreditation, $96.7 \%$ (n: 29) have web page in English, 60\% (n: 18) in Russian, $63.3 \%$ (n: 19) Arabic and $46.7 \%$ (n: 14) in French, German, Dutch, and Roman etc.

$36.7 \%$ (n: 11) of the hospitals that have JCI Accreditation publish patient interpretation and stories on their web pages. Not having a prior experience with health services make opinions, interpretations, and stories of customers with prior experience important. These interpretations and stories are very effective in the process of decision making and as part of trust felt towards the facility. Publication of these comments and stories also demonstrates the trust that the health facility feels for the quality of the service it produces.

$96.7 \%$ (n: 29) of the hospitals that have JCI Accreditation give detailed information on their websites related to the expert staff. Information related to the training received by expert staff, their certificates and courses, their expertise areas and their studies is given on these sites. Together with this, $96.7 \%$ of the hospitals do not explain corporate missions on the website.

Today the websites of health institutions are very functional. These not only provide information, but also make it possible to carry out certain online processes. It is possible to make online booking from the websites of $96.7 \%$ (n: 29) of the hospitals that have JCI Accreditation. Together with this, the websites of the hospitals have alternative processes such as online examination result, online support, and online discussion with the physician, although not included in the research categories.

Since health tourists will be travelling to a culture and environment they do not know in terms of health service's needs, problems and procedures that they may encounter in the target country, including in travelling and transportation problems, may lead to question marks in their heads. Removing these question marks could only be possible by sharing information related to the issue. In this regard, it could be seen that $96.7 \%$ of the hospitals (n: 29) share information related to transportation and travelling alternatives on their websites. Besides, $96.7 \%$ of the hospitals (n: 29) publish information or guides related to potential problems they may encounter and the procedures on their websites. 
Table 3 - Categories related to Facebook pages of hospitals with JCI accreditation

\begin{tabular}{lllllll}
\hline & Yes & \multicolumn{2}{c}{ None } & \multicolumn{3}{c}{ Total } \\
& Number & $\mathbf{\%}$ & Number & $\%$ & Number & $\%$ \\
\hline Freedom to write posts/ comments & 28 & 93,3 & 2 & 6,7 & 30 & 100 \\
Sharing posts on national days & 25 & 83,3 & 5 & 16,7 & 30 & 100 \\
Corporate communication information sharing & 29 & 96,7 & 1 & 3,3 & 30 & 100 \\
Existence of corporate URL address & 29 & 96,7 & 1 & 3,3 & 30 & 100 \\
\hline
\end{tabular}

$96.7 \%$ of the hospitals with JCI accreditation has at least one social media account. Whereas access to these pages could be performed directly over social media page, this could also be done through connections given on the website of the hospital. Whereas $66.7 \%$ (n:20) of the social media contacts given on the web page is found at the top of the website home page, $30 \%$ thereof (n:9) is found at the bottom of the homepage. Facebook is being used by all hospitals that have social media presence. The Facebook page of Acibadem hospital has received 947.757 likes in the period when the research was conducted. Acibadem hospital is followed by Memorial hospital with 697.136 likes. The lowest number of likes is of Private Medina Adana Hospital with 3.276 likes. Whereas $13.3 \%$ (n: 4) of the hospitals under the scope of the research are liked less than 10.000 times, $20 \%$ (n:6) thereof has $10-25.000$ likes and $6.7 \%$ (n:2) thereof have $25.000-50.000$ likes. Whereas $\% 26,7$ of the hospitals are liked between 50.000-100.000 (n:8), rate of hospitals that received 100.000 to 250.000 likes was $10 \%$ (n: 3 ). It could be seen that the rate of hospitals with more than 250.000 likes is $20 \%$ (n:6). In this scope, other information related to Facebook pages are shown in the following table.

Facebook is the most preferred social media platform for individual and corporate users. It enables the enterprise to interact with the target mass. In this regard, $93.3 \%$ (n: 28) of the Facebook pages of hospitals permit writing posts or comments. Together with this, $83.3 \%$ (n: 25) of the hospitals shares various things about the subject on national days. It is thought that these two situations strengthen the interaction with the target mass.

Whereas $73.3 \%$ (n: 22) of the accredited hospitals share Facebook posts once a day, $16.7 \%$ (n: 5) of them share posts twice or multiple times a day. Whereas the rate of those who share Facebook posts several times a month is $3.3 \%$ (n: 1), 3.3\% (n: 1) share posts in once every 2-3 months. Besides, $96.7 \%$ (n: 29) of the hospitals use the logo of the institution as their Facebook profile photo. Information about other social media accounts that cover the hospitals is as follows:

Table 4 - Other social media channels that the hospitals with JCI accreditation use

\begin{tabular}{llllll}
\hline Yes & & None & \multicolumn{3}{c}{ Total } \\
Number & $\%$ & Number & $\%$ & Number & $\%$ \\
\hline
\end{tabular}




\begin{tabular}{lllllll}
\hline Twitter & 29 & 96,7 & 1 & 3,3 & 30 & 100 \\
YouTube & 26 & 86,7 & 4 & 13,3 & 30 & 100 \\
LinkedIn & 12 & 40 & 18 & 60 & 30 & 100 \\
Instagram & 25 & 83,3 & 5 & 16,7 & 30 & 100 \\
Pinterest & 3 & 10 & 27 & 90 & 30 & 100 \\
Google+ & 8 & 26,7 & 22 & 73,3 & 30 & 100 \\
Rss & 2 & 6,7 & 28 & 93,3 & 30 & 100 \\
\hline
\end{tabular}

96.7\% (n: 29) of the hospitals with JCI accreditation use Twitter. Twitter is followed by YouTube with a subscription rate of \%86,7 (n:26) and Instagram with \%83,3 (n:25). LinkedIn site, where information related to business life is shared with the goal of connecting the professionals, is preferred by $40 \%$ (n:8) of the hospitals, and $26.7 \%$ (n:8) of hospitals have Google+ accounts.

Table 5 - Number of followers, subscribers or likes on social medial channels of hospitals with JCI accreditation

\begin{tabular}{|c|c|c|c|c|c|c|c|c|c|c|c|c|c|c|}
\hline & \multicolumn{2}{|c|}{$<1.000$} & \multicolumn{2}{|c|}{$1000-5000$} & \multicolumn{2}{|c|}{$\begin{array}{l}5000- \\
10000\end{array}$} & \multicolumn{2}{|c|}{$\begin{array}{l}10000- \\
25000\end{array}$} & \multicolumn{2}{|c|}{$\begin{array}{l}25000- \\
50000\end{array}$} & \multicolumn{2}{|c|}{$>50000$} & \multicolumn{2}{|c|}{ Total } \\
\hline & $f$ & $\%$ & $f$ & $\%$ & $f$ & $\%$ & $f$ & $\%$ & $f$ & $\%$ & $f$ & $\%$ & $f$ & $\%$ \\
\hline Twitter & 5 & 17,2 & 12 & 41,4 & 2 & 6,9 & 4 & 13,8 & 2 & 6,9 & 4 & 13,8 & 29 & 100 \\
\hline YouTube & 11 & 42,3 & 6 & 23,1 & 3 & 11,5 & 4 & 15,4 & 2 & 7,7 & 0 & 0 & 26 & 100 \\
\hline LinkedIn & 3 & 25 & 3 & 25,0 & 1 & 8,3 & 5 & 41,7 & 0 & 0 & 0 & 0 & 12 & 100 \\
\hline Instagram & 0 & 0 & 12 & 48,0 & 2 & 8,0 & 10 & 40,0 & 1 & 4 & 0 & 0 & 25 & 100 \\
\hline Pinterest & 3 & 100 & 0 & 0 & 0 & 0 & 0 & 0 & 0 & 0 & 0 & 0 & 3 & 100 \\
\hline
\end{tabular}

When the Twitter pages of hospitals with JCI accreditation are examined, it could be seen that Memorial Hospital has 51.537 followers, and it could be seen that the lowest number of followers is of Istanbul Health Sciences University Mehmet Akif Ersoy Chest, Heart and Vein Surgery Training and Research Hospital. Whereas $41.4 \%$ of the hospitals under the scope of research has 1.000 to 5.000 followers, it could be seen that the rate of hospitals that have less than 1.000 followers is $17.2 \%$ (n: 5), and the rate of hospitals with more than 50.000 followers is $13.8 \%$ (n: 4).

When we look at the video sharing site YouTube, it could be seen Acibadem Hospital has the highest number of subscribers with 26.248, and Medicana Hospital has the lowest number of subscribers with $542.3 \%$ (n: 11) of the hospitals under the scope of research have less than 1.000 subscribers. Whereas it could be seen that the rate of hospitals with 10.000 to 25.000 subscribers is $15.4 \%$ (n: 4). None of the hospitals have a YouTube page with more than 50.000 subscribers. 
Medistate Hospital has the highest number of followers on Instagram with 28.258 followers. Kent Hospital appears to have the lowest number of followers with 1.109, whereas \%48 (n: 12) of the hospitals have a number of followers between1.000-5.000, and \%40 have (n:10) 10.000 to 25.000 followers.

Table 6 - Mobile applications related to hospitals

\begin{tabular}{lllllll}
\hline & Yes & & None & & Total \\
& Number & $\%$ & Number & $\%$ & Number & $\%$ \\
\hline Iphone/Ipad operating system & 4 & 13,3 & 26 & 86,7 & 30 & 100 \\
Android operating system & 2 & 6,7 & 28 & 93,3 & 30 & 100 \\
Google operating system & 2 & 6,7 & 28 & 93,3 & 30 & 100 \\
\hline
\end{tabular}

Mobile applications are the software which are prepared, coded and designed especially for smart phones and tablets. It is possible to download these applications for free on smart phones and tablets from stores operated by operating systems. Detailed information as to the operating systems where mobile applications are used, is given in Table $6.13 .3 \%$ (n: 4) of the hospitals within the scope of the research, has a mobile application on one or several platforms. $13.3 \%$ (n: 4) of the hospitals use iPhone/ iPad operating system, $6.7 \%$ (n: 2) use Android operating system, and $6.7 \%$ use Google operating system.

Table 7 - Comparison of digital marketing activities of hospitals with JCI accreditation and thermal facilities

\begin{tabular}{lllll} 
& \multicolumn{2}{c}{ Thermal Facilities } & \multicolumn{2}{c}{ JCI Hospitals } \\
& Number & \% & Number & \% \\
\hline Is there a website in English and in other languages? & 45 & 61,6 & 96,7 & 29 \\
Transportation and traveling opportunities & 66 & 90,4 & 96,7 & 29 \\
Information about the expert staff & 4 & 5,5 & 96,7 & 29 \\
Is there any information/ guide related to problems they & 6 & 8,2 & 96,7 & 29 \\
may encounter and procedures? & & & & 29 \\
Mission statement & 16 & 21,9 & 96,7 & 11 \\
Patient stories & 9 & 12,3 & 36,7 & 29 \\
Does it have Facebook page? & 41 & 56,2 & 96,7 & 29 \\
Does it have Twitter page? & 36 & 49,3 & 96,7 & 29 \\
\hline
\end{tabular}

Thermal facilities and hospitals with JCI accreditation are important service providers for the development of health tourism. Website content and social media platforms that are established in order to get into contact with potential patients and satisfy their information needs, are highly important in terms of reaching the objectives. In this regard, digital marketing activities of thermal facilities and hospitals with JCI accreditation were compared in 8 different categories. 
As it could be seen from Table 7, whereas only $61.6 \%$ of the thermal facilities have web pages in English and other languages, it was seen that this rate was $96.7 \%$ in hospitals. Having a web page at least in English language in order to establish contact with international patients has almost become a golden standard. In all of the hospitals that have JCI accreditation and website access, there are web pages in at least one or several languages, and it can be seen that this rate is $61.6 \%$. It is necessary that the thermal facilities create web pages in at least English language in order to get into contact with international patients.

From these results, it could be seen that the thermal facilities and hospitals with JCI accreditation consider the information related to travelling and transportation opportunities important, and that they share this information on their websites. $90.4 \%$ of the thermal facilities and $96.7 \%$ of the hospitals share this information from the website. It could be seen that information about the expert staff was shared by $5.5 \%$ of the thermal facilities and $96.7 \%$ of the hospitals. It is considered that sharing the information related to expert staff employed in thermal facilities is effective in the decision-making process of the potential customers. In addition to this, the mission statement allows potential customers familiarize themselves with the enterprise's reason of existence. Whereas $21.9 \%$ of the thermal facilities include mission statement on their websites, this rate is $96.7 \%$ in the hospitals.

There is an information asymmetry between the service provided and the beneficiary of the service in health services. This asymmetry increases more when service is to be procured from countries of different culture. This information asymmetry could only be decreased by publishing information or guide related to the problems that the patients could encounter, and the procedures. The rate of those who publish information or guides in relation to problems that thermal facilities could encounter on their websites and the procedures is only $8.2 \%$, and this rate is $96.7 \%$ in the hospitals. Similarly publishing the patient comments and stories is also important for the patients, as the experiences and opinions of people who procure services from the enterprise are more acceptable in recent years compared to the presentation and marketing activities prepared by the enterprise. In this regard, while $12.3 \%$ of thermal facilities respond to patient comments and stories on their websites it can be seen that this rate is realized as a rate of $36.7 \%$ in hospitals?

Social media has become a phenomenon both in individual and corporate use as of 2000s. Whereas $56.2 \%$ of the thermal facilities have a Facebook page, it could be seen that this rate is $96.7 \%$ in hospitals. Similarly, while $49.3 \%$ of thermal facilities have a Twitter page this rate increases up to $96.7 \%$ in hospitals.

\section{Conclusion And Recommendations}

This research aims to examine the digital marketing activities of thermal facilities operating in the field of health tourism and the hospitals with JCI accreditation. In this context, the research evaluated websites and social media sites of 73 thermal facilities as well as the websites, social media sites, and mobile applications of 30 hospitals with JCI accreditation, through the content analysis method. 
The evaluation and comparison concluded that thermal facilities need to develop their digital activities. Results also regarded thermal facilities' lack of a web page in English or any other language as a great shortcoming, as in today's world any enterprise operating in the international market has a website in English.. It is also important for the health institutions to create a web page in the local language of the target market in order to address such markets, and provide a better communication. Furthermore, it appears that only a few thermal facilities include information or guidance related to potential problems patients can encounter and procedures related to expert staff on their websites. In addition, thermal facilities rarely include patient comments and stories on their websites, disregarding that patient comments and stories affect other individuals at a great level. Thermal facilities should address such shortcomings, and produce a more detailed content, responding to patients' questions

Thousand people can view a post shared on social media platforms. Realizing such benefits of the social media, hospitals with JCI accreditation use their social media sites effectively. Thermal facilities can also benefit from such advantage by creating pages on multiple different social media platforms in accordance with the characteristics of the target mass and the needs of their followers. Social media also has a structure that provides interaction. Interacting with potential patients over social media and responding to their needs in a rapid manner addresses the patient's need for information at a low cost, and contributes positively to the image of the enterprise.

Mobile applications constitute another digital platform that has become important with the increasing use of mobile devices such as smart phone and tablet. While the research did not come across the use of mobile applications by thermal facilities, it observed that hospitals with JCI accreditation have at least one operating system. In this regard, both thermal facilities and hospitals with JCI accreditation should develop mobile applications for accessing the websites and realizing the online processes.

As a conclusion, digital marketing activities are very important for both thermal facilities and hospitals with JCI accreditation in order to attract international patients and engage in relationship with them. Enterprises should be present on digital platforms and to establish relationships with potential customers on such platforms. Enterprises should publish pages in at least one foreign language, share contents responding to the information needs of the customers, and establish relationships with the customers on digital platforms. It is also highly important to employ employee(s) in charge of executing activities on these platforms in order to demonstrate an institutional approach on digital platforms. In today's world where we discuss Industry 4.0 and objects contact with each other, failure to have an active presence on the digital platform, may prevent effective competition. Enterprises who want to have competitive advantage should have an effective presence on digital platforms, regardless of the sector.

\section{References}

Cormany, D., \& Baloglu, S. (2011). Medical travel facilitator websites: An exploratory study of web page contents and services offered to the prospective medical tourist. Tourism Management, 32, 709-716. doi:10.1016/j.tourman.2010.02.008 
Crooks, V. A., Turner, L., Snyder, J., Johnston, R., \& Kingsbury, P. (2011). Promoting medical tourism to India: Messages, images, and the marketing of international patient travel. Social Science \& Medicine, 72, 726-732. doi:10.1016/j.socscimed.2010.12.022

Güzel, A. (2014, 12 30). Sağlık Kuruluşlarında Sosyal Medya Pazarlama Faaliyetleri İle Memnuniyet, Marka Güveni ve Marka Sadakati Arasındaki İlişkilerin Yönelik Bir Alan Çalışması. Ankara: Gazi Üniversitesi, Sosyal Bilimler Enstitüsü. Yayınlanmamış Doktora Tezi.

Güzel, A. (2017). Sağlık Turizminde Dijital Pazarlama. D. Tengilimoğlu içinde, Sağlık Turizmi (s. 297-328). Ankara: Siyasal Kitabevi.

Heung, V. C., Kucukusta, D., \& Song, H. (2011). Medical tourism development in Hong Kong: An assessment of the barriers. Journal of Tourism Management, 32, 995-1005.

Holder, D. (2008). What do we mean by direct, data and digital marketing? M. J. Baker, \& S. Hart içinde, The Marketing Book (s. 372-390). Butterworth-Heinemann, Elsevier.

Hopkins, L., Labonte', R., \& Runnels, V. (2010). Medical tourism today: What is the state of existing knowledge? Journal of Public Health Policy, 31(2), 185-198.

JCI. (2018). Who is JCI. 31 03, 2018 tarihinde Joint Commission International: https://www.jointcommissioninternational.org/about-jci/who-is-jci/adresinden alınd1

Kannan, P., \& Li, H. (2016). Digital marketing: A framework, review and research agenda. International Journal of Research in Marketing, 34, 22-45. doi:http://dx.doi.org/10.1016/j.ijresmar.2016.11.006

Kemp, S. (2017, 01 24). Digital in 2017: Global Overview. 03 11, 2018 tarihinde We Are Social: https://wearesocial.com/special-reports/digital-in-2017-global-overview adresinden alınd 1

Kemp, S. (2017, 08 10). Three billion people now use social media. 08 10, 2017 tarihinde We are social: https://wearesocial.com/blog/2017/08/three-billion-people-now-use-socialmedia adresinden alınd 1

Khan, A., \& Khan, R. (2012). Embracing new media in Fiji: the way forward for social network marketing and communication strategies. Strategic Direction, 4, 3-5.

KTB. (tarih yok). Türkiye'de Sağllk ve Termal Turizm. 03 31, 2018 tarihinde T.C. KÜLTÜR VE TURIZM BAKANLIĞI YATIRIM VE İŞLETMELER GENEL MÜDÜRLÜĞ̈̈: http://yigm.kulturturizm.gov.tr/TR,11479/turkiyede-saglik-ve-termal-turizm.html adresinden alınd 1

Lunt, N., Horsfall, D., \& Hanefeld, J. (2016). Medical tourism: A snapshot of evidence on $\begin{array}{llll}\text { treatment } \quad \text { abroad. } & \text { Maturitas, } & \text { 37-44. }\end{array}$ doi:https://doi.org/10.1016/j.maturitas.2016.03.001

Mucan, B., \& Özeltürkay, E. Y. (2014). Social Media Creates Competitive Advantages: How Turkish Banks Use This Power? A Content Analysis of Turkish Banks through Their Webpages. Procedia - Social and Behavioral Sciences, 148, 137-145. doi:10.1016/j.sbspro.2014.07.027

Osatuyi, B. (2013). Information sharing on social media sites. Computers in Human Behavior, 29, 2622-2631.

Resmi Gazete. (2018, 07 01). Kaplıcalar Yönetmeliği. 03 30, 2018 tarihinde Halk Sağlı̆̆ı Genel Müdürlüğü, Çevre Sağlığı Daire Başkanlığı: http://cevresagligi.thsk.saglik.gov.tr/2013- 
08-28-13-18-43/mevzuat/972-kap1\%C4\%B1calar-y\%C3\%B6netmeli\%C4\%9Fi.html adresinden alınd 1

Saturk. (tarih yok). Türkiye'de Termal Sağllk Turizmi. 31 03, 2018 tarihinde Sağlık Turizmi Koordinasyon Kurulu: http://www.saturk.gov.tr/images/pdf/tyst/07.pdf adresinden alınd1

Statista.com. (2018, 01 27). Most famous social network sites worldwide as of January 2018, ranked by number of active users (in millions). 03 30, 2018 tarihinde Statista: https://www.statista.com/statistics/272014/global-social-networks-ranked-by-numberof-users/ adresinden alınd 1

Wagle, S. (2013). Web-based medical facilitators in medical tourism: the third party in decision-making. Indian Journal of Medical Ethics, 10(1), 28-33. doi:https://doi.org/10.20529/IJME.2013.006

Yasmin, A., Tasneem, S., \& Fatema, K. (2015). Effectiveness of Digital Marketing in the Challenging Age: An Empirical Study. International Journal of Management Science and Business Administration, 1(5), 69-80.

Yeoh, E., Othman, K., \& Ahmad, H. (2013). Understanding medical tourists: Word-of-mouth and viral marketing as potent marketing tools. Tourism Management, 34, 196-201. doi:10.1016/j.tourman.2012.04.010 